\title{
Sistem Cerdas Reservasi dan Pemantauan Parkir pada Lokasi Kampus Berbasis Konsep Internet of Things
}

\author{
Dody Ichwana*), Ratna Aisuwarya, Styviandra Ardopa, Indah Purnama \\ Jurusan Sistem Komputer, Fakultas Teknologi Informasi, Universitas Andalas \\ Kampus Unand Limau Manis, Padang, Indonesia 25163
}

Cara sitasi: D. Ichwana, R. Aisuwarya, S. Ardopa, and I. Purnama, "Sistem Cerdas Reservasi dan Pemantauan Parkir pada Lokasi Kampus Berbasis Konsep Internet of Things," Jurnal Teknologi dan Sistem Komputer, vol. 6, no. 2, Apr. 2018. doi: 10.14710/jtsiskom.6.2.2018.57-63, [Online].

\begin{abstract}
At present time, the people who use vehicles on the campus is increasing. It makes more difficult to find an empty slot parking area on the campus. This study aims to develop a system parking reservation and monitoring on-campus area using NFC and IoT concept. NFC was used to confirm booking code that generated by the system. In the parking area, ultrasonic sensors were installed to detect parking space availability. IoT concept has been applied to build this system. Apps on users smartphone can do the reservation process to the desired parking location via internet. Black box testing was done by building a prototype using the number of data locations parking slots in the Andalas University. The test results showed that this system has been able to detect the location of vacant parking slots and do reservations with time to send data to the server for $0.7952 \mathrm{sec}$.
\end{abstract}

Keywords - smart parking reservation; NFC; smart campus; IoT

\begin{abstract}
Abstrak - Penggunaan kendaraan yang semakin meningkat di lokasi kampus pada saat ini mengakibatkan semakin sulitnya menemukan tempat parkir kosong. Penelitian ini bertujuan untuk mengembangkan sistem reservasi dan pemantauan parkir pada lokasi kampus menggunakan NFC dan konsep IoT. NFC digunakan untuk melakukan konfirmasi dari kode pemesanan yang telah dihasilkan oleh sistem. Pada lokasi parkir, sensor jarak ultrasonik dipasang untuk mendeteksi ketersediaan parkir. Konsep IoT telah diterapkan untuk membangun sistem ini. Aplikasi pada perangkat telepon cerdas telah berhasil melakukan reservasi pada lokasi parkir yang diinginkan melalui Internet. Pengujian sistem dilakukan dengan pengujian kotak menggunakan data uji jumlah tempat parkir yang ada di lingkungan kampus Universitas Andalas. Hasil pengujian menunjukkan bahwa sistem telah mampu mendeteksi lokasi parkir yang kosong dan melakukan reservasi dengan waktu pengiriman data ke server selama 0.7952 detik.
\end{abstract}

Kata Kunci - reservasi parkir cerdas; NFC; smart campus; IoT

*) Penulis korespondensi (Dody Ichwana)

Email : dody.ichwana@fti.unand.ac.id

\section{Pendahuluan}

Perkembangan jumlah civitas akademika di suatu kampus semakin meningkat saat sekarang ini seiring dengan semakin banyaknya mahasiswa yang terdaftar di suatu kampus. Hal ini menyebabkan terjadinya peningkatan jumlah pengguna kendaraan di lingkungan kampus. Permasalahan yang timbul adalah semakin sulitnya mencari lahan parkir yang kosong. Pemantauan parkir kendaraan dan manajemen lokasi parkir menjadi salah satu isu besar di lokasi kampus akibat dari pertambahan jumlah kendaraan ini [1]. Isu serupa juga terjadi di Universitas Andalas. Kondisi lahan parkir yang kurang teratur membuat jalur keluar dan jalur masuk kendaraan di lingkungan kampus menjadi sempit sehingga menimbulkan kemacetan. Ketidakteraturan posisi kendaraan pada lahan parkir menyebabkan ruang untuk masing-masing kendaraan tidak dapat diisi sesuai dengan kapasitasnya. Kemacetan yang ditimbulkan membuat kerugian waktu dan biaya. Hal ini menimbulkan ketidaknyamanan bagi pengemudi, khususnya pengemudi mobil terutama di jam padat [2], [3].

Pengaturan lahan parkir secara manual tidak lagi solusi efektif mengatasi masalah parkir. Salah satu penyebab masalah parkir adalah kurangnya informasi lahan parkir kosong yang diketahui pengemudi, sehingga pengemudi mobil kesulitan dalam memarkirkan kendaraan mereka dan terkadang parkir di sembarang tempat. Hal ini menjadi tantangan tersendiri agar dapat merancang suatu sistem parkir yang dapat mengatur letak parkir mobil dan memberikan informasi untuk setiap tempat parkir yang tersedia.

Perkembangan teknologi komunikasi perangkat tanpa kabel yang berkembang secara pesat mendorong terbentuknya berbagai sistem yang dapat memantau suatu objek secara otomatis. Banyaknya masyarakat yang menggunakan devais bergerak yang terhubung ke Internet membuat aliran data menjadi semakin cepat. Chauhan dkk. [4] menyatakan bahwa aplikasi bergerak mempunyai kemampuan untuk melakukan manajemen lokasi parkir secara efektif. Kemunculan Internet Of Things (IoT) memungkinkan perangkat komputer secara otomatis dapat melakukan kontrol terhadap suatu sistem dan memungkinkan pula untuk memberi aksi ke sistem terhadap kejadian yang terjadi pada sistem yang 


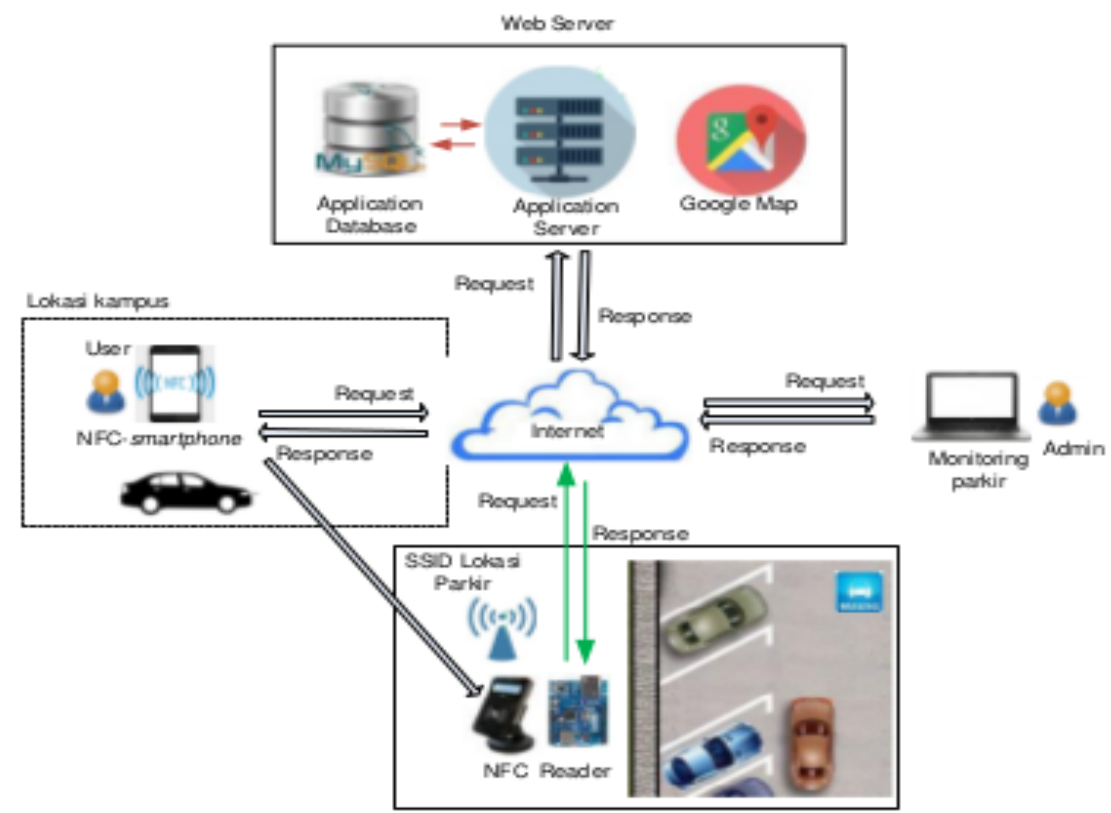

Gambar 1. Arsitektur sistem reservasi dan pemantauan parkir

dikontrol secara realtime [5]. IoT dapat menyediakan layanan parkir yang dapat dipantau melalui data yang tersimpan di dalam basis data dan dapat diakses melalui web [6], [7].

Solusi dari masalah pencarian lahan parkir kosong adalah dengan membangun sistem online berupa aplikasi bergerak pencarian lahan parkir kosong yang dapat membantu pengendara menemukan lahan parkir kosong secara cepat, aman dan mudah, seperti [1]-[3], [5]-[7], [9]-[13]. Kontrol terhadap suatu sistem yang dibuat dapat dilakukan dimana pun dengan memanfaatkan perangkat bergerak. Dengan adanya sistem IoT, dapat dibentuk sebuah sistem untuk mengontrol ketersediaan tempat parkir yang masih tersedia dan mengetahui lokasinya. Pengguna dapat mengetahui ketersediaan tempat parkir dengan mengakses aplikasi yang terhubung dengan Internet dengan cepat [3], [5], [7]. Waktu dan tenaga yang terbuang hanya untuk menemukan tempat parkir yang kosong dapat dikurangi [9].

Alkahrusi dan Al Bahadly [11] mengembangkan sistem parkir yang menggunakan kamera untuk mendeteksi lokasi parkir, namun sistem ini tidak mampu mendeteksi lokasi parkir jika lokasi terhalang oleh suatu benda. Shen en dan Hsiang [12] mengembangkan sistem berbasis kamera juga yang tergantung pada cuaca untuk mendapatkan gambar yang baik. Pemantauan parkir menggunakan aplikasi Android dilakukan oleh Bonde dkk [13] dan proses pemantauan dilakukan ketika pengguna telah berada di gerbang parkir. Phams dkk. [14] serta Hans dan Sethi [15] mengembangkan sistem parkir pintar, namun tidak mempunyai fasilitas pencarian parkir kosong dan pemantauan jumlah parkir pada suatu area parkir. Penelitian ini bertujuan mengembangkan sistem parkir yang mampu melakukan pemantauan jumlah parkir yang kosong menggunakan sensor jarak ultrasonik dan melakukan reservasi lokasi parkir tersebut dengan memanfaatkan IoT sehingga sistem dapat dipantau di mana saja menggunakan telepon cerdas.

\section{Metode Penelitian}

Kebutuhan fungsional dari sistem reservasi parkir ini adalah sistem mampu mengetahui lokasi parkir kosong, sistem mampu melakukan reservasi parkir, sistem mampu memandu pengguna ke lokasi parkir yang dipilih, dan sistem mampu melakukan pemantauan parkir. Purwarupa lokasi parkir digunakan pada penelitian ini untuk menerapkan rancangan sistem yang telah dibangun. Data uji yang digunakan untuk implementasi adalah data jumlah dan lokasi parkir mobil di setiap gedung yang ada di lingkungan kampus Universitas Andalas. Arsitektur sistem diperlihatkan pada Gambar 1.

Perancangan sistem dilakukan dengan menyatakan spesifikasi fungsional sistem, mulai sejak akuisisi data hingga luaran hasil didapatkan oleh pengguna. Secara sistematis, alur fungsi sistem dapat dilihat pada diagram aktivitas sistem. Pada Gambar 2 diperlihatkan diagram aktivitas pengguna terhadap sistem dan Gambar 3 diperlihatkan diagram aktivitas Admin terhadap sistem.

Telepon cerdas yang dimiliki oleh pengguna harus terkoneksi dengan Internet agar dapat login dan dapat mengakses data pada server. Setelah proses login selesai, pengguna dapat memilih tempat parkir yang diinginkan. Jika masih tersedia ruang kosong untuk parkir, maka pengguna dapat memesan tempat parkir tersebut. Setelah proses pemesanan selesai, server mengirimkan kode pemesanan ke pengguna yang telah melakukan proses pemesanan parkir. Setelah melakukan pemesanan lokasi parkir, pengguna diberi waktu \pm 10 menit untuk menuju ke tempat parkir yang telah dipesan tersebut untuk melakukan tag konfirmasi bahwa pengguna sudah berada di lokasi tersebut. Jika pengguna lewat dari waktu yang diberikan, maka 


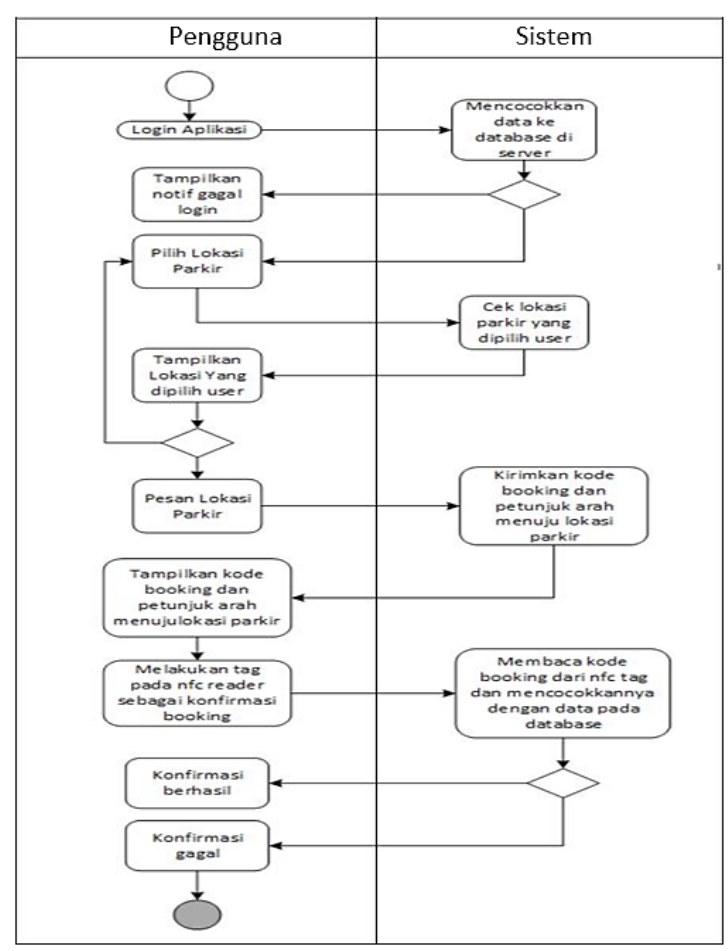

Gambar 2. Diagram aktivitas pengguna terhadap sistem

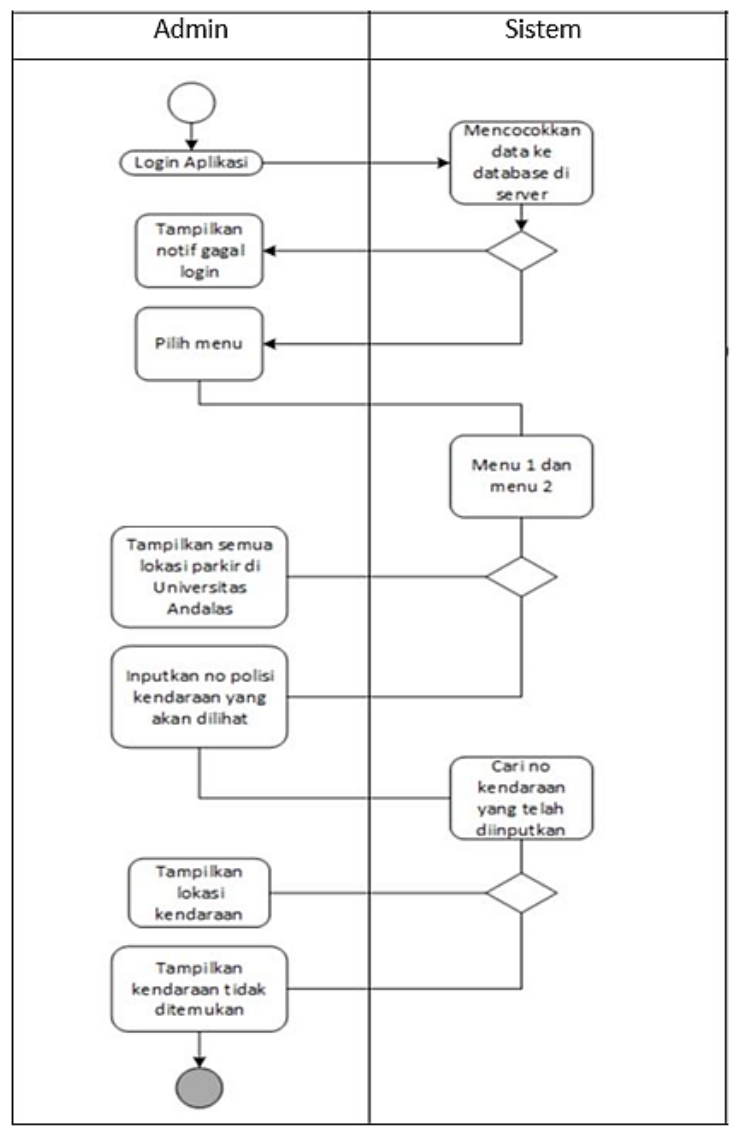

Gambar 3. Diagram aktivitas Admin terhadap sistem

pengguna harus melakukan pemesanan ulang karena pemesanan lokasi parkir sebelumnya akan otomatis dibatalkan oleh sistem.

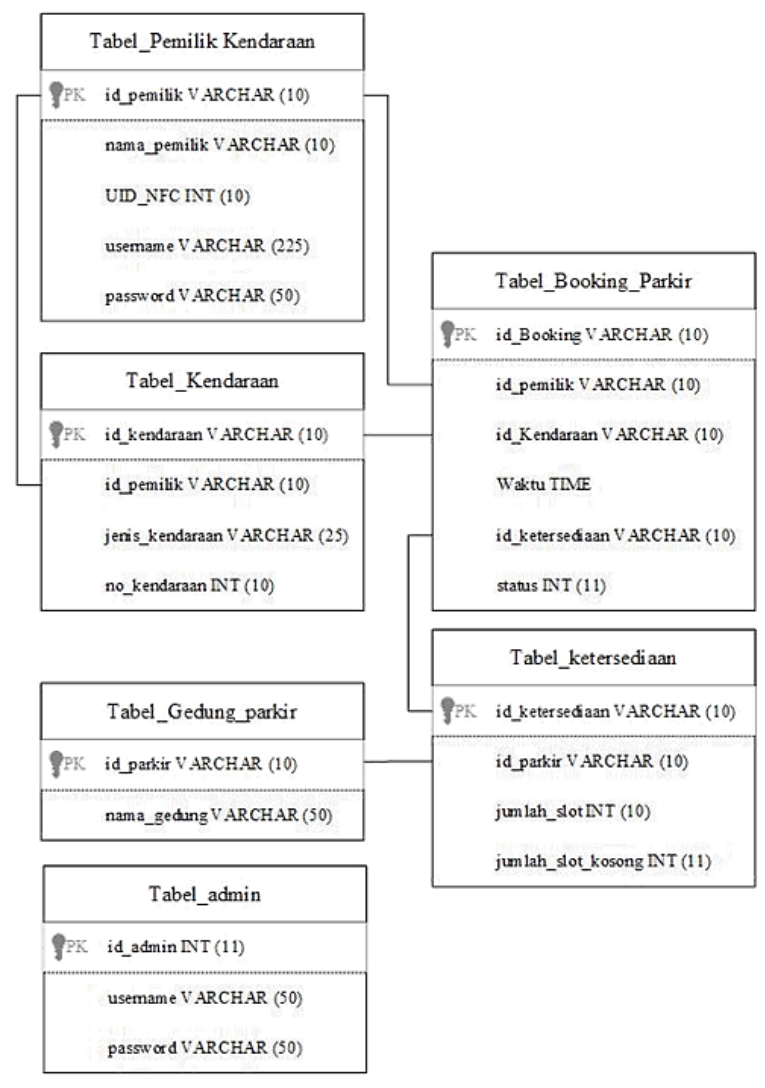

Gambar 4. Rancangan basis data

Ketika pengguna sudah sampai di lokasi parkir yang telah dipesan sebelumnya, maka pengguna harus melakukan konfirmasi bahwa pengguna telah sampai pada lokasi tersebut dengan cara mendekatkan telepon cerdas pengguna ke pembaca NFC untuk pembacaan kode pemesanan yang telah dikirim server sebelumnya. Setelah itu, sistem mengirimkan kode pemesanan tersebut kembali ke server untuk dicocokkan dengan data yang ada di server. Jika cocok, maka proses selesai dan pengguna dapat melakukan parkir. Pada penelitian ini, data parkir tersimpan pada basis data yang terdiri dari enam tabel yaitu tabel login, tabel booking parkir, tabel kendaraan, tabel pemilik kendaraan, tabel ketersediaan dan tabel gedung parkir. Rancangan basis data dapat dilihat pada Gambar 4.

Proses penentuan lokasi parkir kosong dilakukan oleh sensor ultrasonik yang dipasang di setiap ruang parkir. Pada sistem ini, sensor ultrasonik mengirim hasil pengukuran jarak berupa data digital ke mikrokontroler dan disimpan ke basis data melalui Internet, data dari sensor ultrasonik dikirim secara terus menerus oleh sistem. Proses pencarian lokasi parkir kosong diperlihatkan pada Gambar 5. Sistem memandu pengguna yang telah melakukan reservasi parkir menuju ke lokasi yang telah dipesan melalui aplikasi di telepon cerdas Android. Setiap pengguna yang melakukan reservasi dan telah memarkirkan kendaraannya di lokasi parkir dipantau identitasnya oleh sistem sehingga memungkinkan Admin untuk mengetahui identitas siapa saja yang berada di lokasi kampus saat ini.

Perangkat keras yang digunakan sebagai pembaca kode pemesanan proses reservasi dari telepon cerdas 


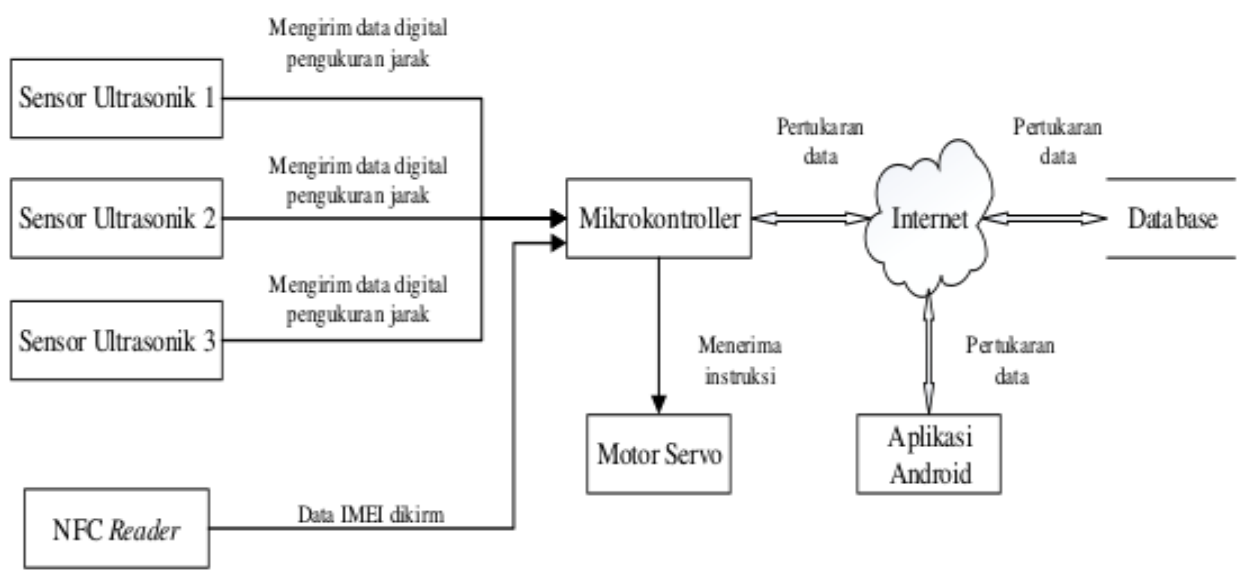

Gambar 5. Proses pencarian lokasi parkir kosong

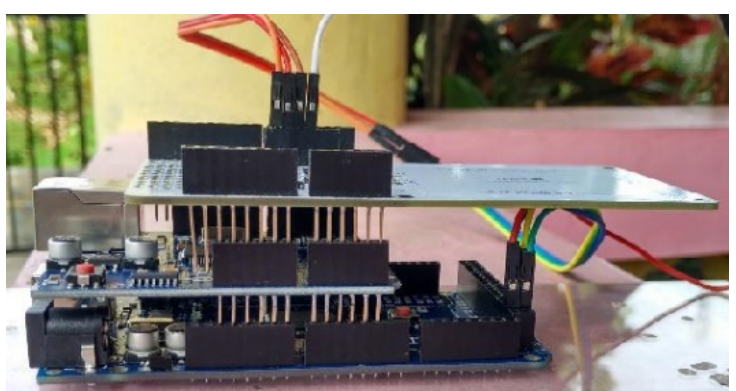

Gambar 6. Implementasi perangkat keras pembaca kode pemesanan

\begin{tabular}{|c|c|c|c|}
\hline Unand Parkir & \multicolumn{2}{|l|}{ Montoring Cari Kendaraan } & \multirow[b]{2}{*}{ Jumlah Slot Kosong } \\
\hline No. & Nama Gedung & Jumlah Slot & \\
\hline 1 & Fakutas Ekonomi Depan & 22 & 11 \\
\hline 2 & Fakuthas Teknologi Informasi & 41 & 72 \\
\hline 3 & Fakultas Keperawatan & 30 & 15 \\
\hline 4 & Fakultas Kedokteran 1 & 9 & 4 \\
\hline 5 & Fakutas Keookteran 2 & 20 & 5 \\
\hline 6 & Fakuntas Psikologi & 10 & 3 \\
\hline 7 & Fakutas Hukum & 25 & 5 \\
\hline 8 & Fakultas IImu Sosial dan Imu Polita & 17 & 5 \\
\hline 9 & Fakutas IImu Budaya & 20 & 11 \\
\hline 10 & Gedung A & 52 & 10 \\
\hline 11 & Gedung D & 8 & 0 \\
\hline 12 & Fakultas Ekcnomi Belakang & 30 & 5 \\
\hline 13 & Geoung $E$ & 21 & 8 \\
\hline 14 & Gedung $F$ Depan & 18 & 5 \\
\hline 15 & Gedung F Beliskang & 43 & 6 \\
\hline
\end{tabular}

Gambar 7. Halaman web pemantauan parkir

pengguna adalah pembaca NFC PN532 shield, Arduino Mega, dan ethernet shield. Pengembangan perangkat lunak dilakukan dengan Android Studio, Arduino IDE, PHP, basis data MySQL pada XAMPP. Pada penelitian ini, pengujian sistem dilakukan dengan metode black box berdasarkan kebutuhan fungsional sistem yang telah dibangun.
Tabel 1. Hasil pengujian jarak baca antara perangkat keras pembaca kode pemesanan dengan telepon cerdas pengguna

\begin{tabular}{cccccc}
\hline \multirow{2}{*}{ Percobaan } & \multicolumn{5}{c}{ Jarak } \\
\cline { 2 - 5 } & $0 \mathrm{~cm}$ & $1 \mathrm{~cm}$ & $2 \mathrm{~cm}$ & $3 \mathrm{~cm}$ & $4 \mathrm{~cm}$ \\
\hline 1 & Terbaca & Terbaca & Terbaca & Tidak & Tidak \\
2 & Terbaca & Terbaca & Terbaca & Terbaca & Tidak \\
3 & Terbaca & Terbaca & Terbaca & Terbaca & Tidak \\
4 & Terbaca & Terbaca & Terbaca & Tidak & Tidak \\
5 & Terbaca & Terbaca & Terbaca & Terbaca & Tidak \\
6 & Terbaca & Terbaca & Terbaca & Tidak & Tidak \\
7 & Terbaca & Terbaca & Terbaca & Terbaca & Tidak \\
8 & Terbaca & Terbaca & Terbaca & Tidak & Tidak \\
9 & Terbaca & Terbaca & Terbaca & Terbaca & Tidak \\
10 & Terbaca & Terbaca & Terbaca & Terbaca & Tidak \\
\hline
\end{tabular}

\section{Hasil dan Pembahasan}

Proses pemantauan jumlah kendaraan yang sedang parkir di setiap gedung perkuliahan dipantau dengan menggunakan laman pemantauan parkir. Jumlah kendaraan yang terpantau dilaporkan secara realtime berdasarkan perubahan data kendaraan yang sedang parkir di setiap gedung. Hasil implementasi dari perangkat keras pembaca kode pemesanan diperlihatkan pada Gambar 6 dan laman pemantauan parkir ini dapat dilihat pada Gambar 7.

Pengujian perangkat keras pembaca kode pemesanan reservasi dilakukan dengan dua pengujian. Pengujian pertama bertujuan untuk mengetahui jarak yang dibutuhkan antara perangkat telepon cerdas pengguna dengan perangkat keras pembaca kode pemesanan (pembaca NFC) untuk proses pembacaan kode pesan. Pengujian kedua bertujuan untuk mengetahui waktu respons pengiriman data yang telah dibaca oleh perangkat keras pembaca kode pemesanan ke server. Hasil pengujian jarak pembacaan dapat dilihat pada Tabel 1 dan hasil pengujian waktu respons ditampilkan dalam grafik yang terlihat pada Gambar 8 . Berdasarkan hasil pengujian pertama dan kedua dapat dinyatakan jarak baca antara perangkat keras pembaca kode pemesanan dan telepon cerdas pengguna berada 


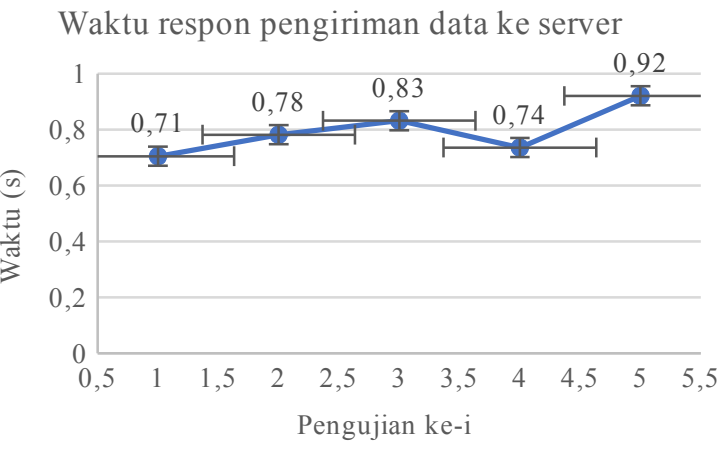

Gambar 8. Grafik respons waktu pengiriman data dari perangkat keras pembaca kode pemesanan ke server

pada rentang $0-3 \mathrm{~cm}$ dan rata-rata waktu pengiriman data ke server adalah 0.7952 detik.

Pengujian sistem secara keseluruhan dilakukan dengan metode black box dengan memperhatikan hasil eksekusi dari sistem yang diberi masukan data uji yang telah ditetapkan. Pengujian ini dilakukan dengan menggunakan skenario pemakaian sistem, seperti ditunjukkan dalam Gambar 9. Skenario yang digunakan adalah pengguna berada di dekat gerbang Universitas Andalas dan ingin menuju gedung Convention Hall, pengguna melakukan proses login pada aplikasi dan memilih gedung lokasi tempat parkir. Proses login dan pemilihan lokasi ini dapat dilihat pada Gambar 9(a) dan Gambar 9(b). Setelah pengguna menekan tombol pemesanan, pengguna akan mendapatkan kode pemesanan yang dihasilkan oleh sistem. Kode pemesanan ini terlihat pada Gambar 9(c). Sistem selanjutnya akan menunjukkan rute ke lokasi gedung parkir dengan visualisasi peta Google map dengan jarak $1,6 \mathrm{~km}$ dan perkiraan waktu tempuh selama 5 menit, seperti diperlihatkan dalam Gambar 9(d).

Setelah sampai di gedung yang dituju, pengguna harus melakukan konfirmasi bahwa telah berada di lokasi gedung yang dituju dengan menempelkan telepon cerdasnya ke pembaca NFC. Gambar 10 menunjukkan proses tag telepon cerdas pengguna ke perangkat keras pembaca kode pemesanan. Pada proses pemesanan ini kode pemesanan yang dihasilkan oleh aplikasi adalah 196143. Kode pemesanan ini terdiri dari data integer sebanyak 4 digit yang dihasilkan secara acak oleh aplikasi. Kode ini selanjutnya akan dikirimkan aplikasi ke server dan disimpan di dalam basis data sistem.

Setelah aplikasi menghasilkan kode pemesanan parkir, aplikasi selanjutnya akan menggabungkan data kode pemesanan sebagai id booking, data gedung lokasi parkir sebagai id parkir dan data UID NFC pada telepon cerdas pengguna sebagai UID_NFC. Ketiga data ini digabung dalam format \{id_booking, id_parkir, UID_NFC $\}$ dan dikirimkan ke server. Data id_booking akan disimpan di dalam tabel Tabel_Booking_Parkir. Data UID_NFC dan id_booking yang ada di basis data akan dicocokkan dengan data setelah pengguna melakukan konfirmasi parkir di lokasi parkir. Jika data
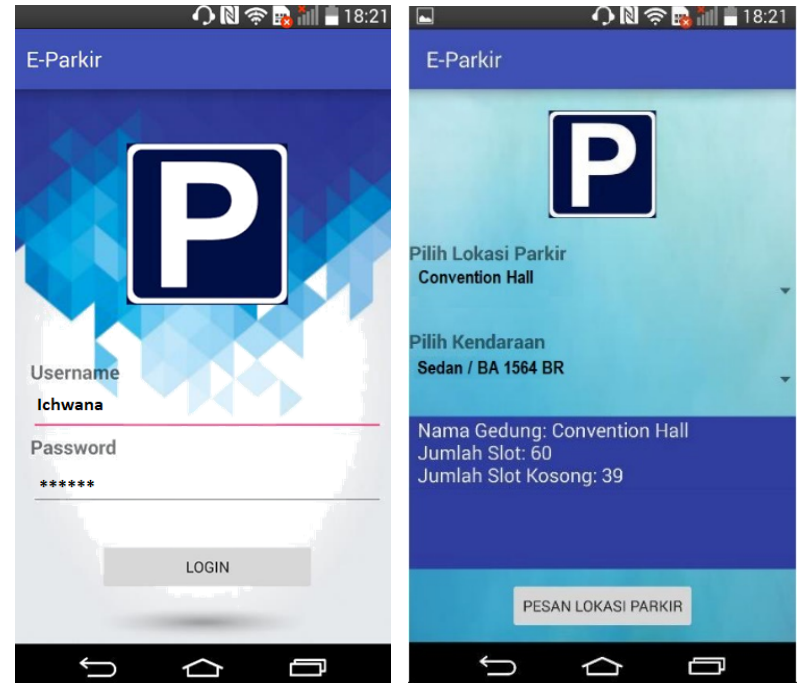

(a) login pengguna

(b) pemilihan lokasi gedung
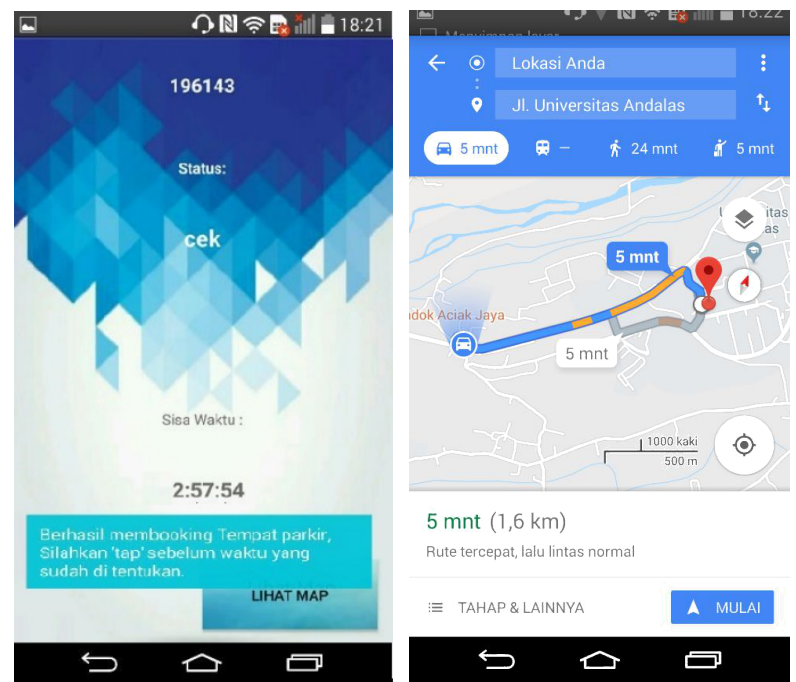

(c) kode pemesan parkir

(d) peta dan jalur parkir

Gambar 9. Antarmuka aplikasi telepon cerdas Android

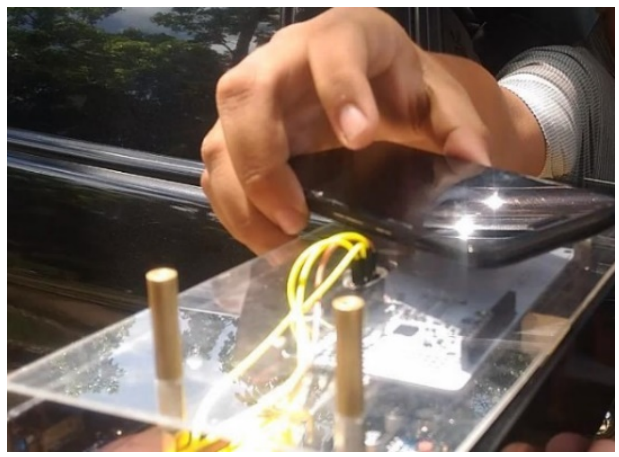

Gambar 10. Pengguna melakukan tag telepon cerdas ke perangkat keras pembaca kode pemesanan

yang dibandingkan cocok, maka jumlah lokasi parkir kosong akan dikonfirmasi ke dalam basis data.

Data yang dibaca oleh pembaca NFC PN532 pada perangkat keras pembaca kode pemesanan adalah kode pemesanan dan UID NFC telepon cerdas pengguna. Jika kode pemesanan yang dibaca oleh pembaca NFC sama 


\begin{tabular}{l} 
W0 COM3 (Arduino/Genuino Mega or Mega 2560) \\
\hline Waiting for message from Peer \\
NDEF Record 1 \\
TNF: 2 \\
TYpe: Kode Booking \\
Kode: 196143 \\
GET / UnandParkir/API.php?action=bookingspayload=196143 HTTP/1.1 \\
connected \\
81.72 \\
Memulai scanning \\
Card Scanning Starts... \\
Waiting for message from Peer \\
\hline
\end{tabular}

$\square$ Autoscroll

No line ending $\checkmark 115200$ baud $\checkmark \quad$ Clear output

Gambar 11. Proses pencocokan data id_booking dan data UID_NFC pada telepon cerdas pengguna dengan data di basis data

dengan data yang ada pada server web, maka konfirmasi pemesanan berhasil. Proses pembacaan kode pemesanan dan UID NFC diperlihatkan pada Gambar 11. Data id_booking yang tersimpan dalam basis data adalah 96143. Jika data ini cocok dengan data pada saat konfirmasi, maka proses reservasi parkir selesai. Nilai tersebut merupakan data yang diminta oleh aplikasi Android yang disimpan pada basis data. Dengan demikian proses penyimpanan data aplikasi Android pada server web berhasil dilakukan.

Penelitian telah menghasilkan sistem untuk mengelola parkir secara cerdas seperti halnya dalam [1][3], [5]-[7], [9]-[13]. Konsep IoT untuk sistem parkir diterapkan dalam penelitian ini untuk area kampus, seperti dalam [2], [5], [9] untuk smart city dan [7] untuk bandara. Sistem dalam penelitian ini memungkinkan pengguna untuk memesan area dan lokasi parkir yang dikehendaki menggunakan perangkat Android, seperti halnya dalam [13]-[15] dengan mengakses lewat aplikasi web untuk memesan lokasi. Berbeda halnya dengan [13]-[15], perangkat Android ini kemudian dijadikan sebagai devais untuk otorisasi di area dan lokasi parkir melalui pembacaan ID NFC devais tersebut dengan waktu respons kurang dari 1 detik. Penggunaan dan ketersediaan tempat parkir dideteksi oleh sensor ultrasonik yang terpasang di tiap tempat parkir. Penggunaan kamera, seperti dalam [11]-[13], dapat diterapkan sebagai pelengkap sistem dalam penentuan ketersediaan tempat. Algoritma pengolahan citra diterapkan untuk mengenali mobil dan ruang kosong di lahan parkir.

\section{KESIMPULAN}

Penelitian ini telah berhasil membangun dan mengimplementasikan sistem cerdas reservasi dan pemantauan parkir pada lokasi kampus melalui aplikasi yang berjalan di sistem operasi Android dengan menerapkan konsep IoT. Sistem dapat mengetahui lokasi parkir yang kosong dan mampu melakukan reservasi untuk lokasi parkir kosong tersebut menggunakan telepon cerdas Android serta dapat melakukan pemantauan parkir di lokasi kampus.

\section{UCAPAN TERIMA KASIH}

Ucapan terima kasih ditujukan kepada Universitas Andalas melalui Program Penelitan Dosen Pemula tahun 2017, No Kontrak : 09/UN.16.15/PL/FTI-2017.

\section{Daftar Pustaka}

[1] M. Y. Aalsalem, dan Z. W. Khan, "CampusSense A Smart Vehicle Parking Monitoring and Management System using ANPR Cameras and Android Phones," ICACT Transactions on Advanced Communications Technology (TACT), vol. 5, no. 2, pp. 809-815, March, 2016.

[2] B. M. Kumar Gandhi, dan M. K. Rao, "A Prototype for IoT based Car Parking Management System for Smart Cities," Indian Journal of Science and Technology, vol. 9, no. 17, May 2016.

[3] N. Moses, dan Y. D. Chincholkar, "Smart Parking System for Monitoring Vacant Parking," International Journal of Advanced Research in Computer and Communication Engineering, vol. 5, no. 6, pp. 717-720, June 2016.

[4] S. Chauhan, C. Pramanik, A. Chauhan, A. Patil, dan S. Das, "Survey Paper on Internet of Things Based Smart Vehicular Parking System," International Journal of Innovative Research in Computer and Communication Engineering, vol. 4, no. 10, 2016.

[5] M. Fraifer, dan M. Fernström, "Designing an IoT Smart Parking Prototype System," in Thirty Seventh International Conference on Information Systems, Dublin, 2016.

[6] Y. Zheng, dan S. Rajasegarar, "Parking Availability Prediction for Sensor-enabled Car Parks in Smart Cities," in 2015 IEEE Tenth International Conference on Intelligent Sensors, Sensor Networks and Information Processing (ISSNIP), Singapore, Apr 2015.

[7] M. Suresh, K. Saravara, dan Sundarajan, "IoT based Airport Parking System," in IEEE 2nd International Conference on Innovations in Information Embedded and Communication Systems, Apr 2015.

[8] F. Faheem, dan S. Mahmud, "A Survey of Intelligent Car Parking System," Journal of Applied Research and Technology, vol. 11, no. 5, pp. 714-726, October 2013.

[9] V. D. Ichake, P. D. Shitole, dan M. Momin, "Smart Car Parking System Based on IoT Concept," International Journal of Engineering Science Invention, vol. 5, no. 3, pp. 48-54, March 2016.

[10] D. Ichwana, dan W. Syahputra, "Sistem Pembayaran Parkir Menggunakan Near Field Communication Berbasis Android dan Teknologi Internet of Things," Teknologi dan Sistem Informasi (Teknosi), vol. 3, no. 1, pp. 153-164, 2017.

[11] H. Alkahrusi, dan I. Al Bahadly, "Intelligent Parking Management System Based on Image Processing," World Journal of Engineering and Technology, vol. 2, no. 1, pp. 55-67, 2014. 
[12] S. Shen en, dan W. Hsiang, "A Convenient Visionbased System for Automatic Detection of Park Spaces in Indoor Parking lots using Wide Angle Cameras," IEEE Transaction on Vehicular Technology, vol. 63, no. 6, 2014.

[13] D. Bonde, R. S. Ketan, dan S. Gaiklwal, "Automated Car Parking System Commanded By Android Application," dalam International Conference on Computer Communication and Informatics (ICCCI 2014), LohgaonPune, India, 2014.
[14] T. N. Pham, M. F. Tsia, D. B. Nguyen, C. R. Dow, dan D. J. Deng, "A Cloud Based Smart Parking System Based on Internet of Things Technology," IEEE Access, vol. 3, September 2015.

[15] V. Hans, dan P. S. Sethi, "An Approach to Iot Based Car Parking and Reservation System on Cloud," dalam International Conference on Green Computing and Internet of things (ICGCIoT), India, 2015. 